\title{
In situ production and respiration of the benthic community during emersion on subtropical intertidal sandflats
}

\author{
Li-Hua Lee ${ }^{1,2}$, Li-Yung Hsieh ${ }^{1,2}$, Hsing-Juh Lin ${ }^{2,3, *}$ \\ ${ }^{1}$ Endemic Species Research Institute, Jiji, Nantou 552, Taiwan \\ ${ }^{2}$ Department of Life Sciences, National Chung Hsing University, Taichung 402, Taiwan \\ ${ }^{3}$ Biodiversity Research Center, Academia Sinica, Taipei 115, Taiwan
}

\begin{abstract}
In situ benthic community production and respiration during emersion were measured monthly in the course of a 19 mo survey from June 2008 to December 2009 by monitoring $\mathrm{CO}_{2}$ fluxes in benthic chambers on intertidal sandflats of a subtropical coastal wetland. Maximum gross community production $\left(\mathrm{GCP}_{\mathrm{m}}\right)$ and community respiration $(\mathrm{CR})$ all exhibited higher values in summer and fall and lower values in spring and winter. $\mathrm{GCP}_{\mathrm{m}}$ and $\mathrm{CR}$ were positively correlated with air temperature. Temperature coefficients $\left(Q_{10}\right)$ showed that a rise of $10^{\circ} \mathrm{C}$ would increase the $\mathrm{GCP}_{\mathrm{m}}$ and $\mathrm{CR}$ by factors of 3.72 and 4.80 , respectively. $\mathrm{GCP}_{\mathrm{m}}$ was also positively correlated with sediment grain size and negatively correlated with the silt/clay content. CR exhibited a strong positive correlation with sediment chlorophyll a concentration and macrofaunal biomass. To provide an accurate annual budget of benthic production during emersion, corrections were considered for cloudiness and the time lag between emersion and maximum production due to vertical migration of benthic diatoms and variations in CR during nighttime emersion periods. Annual net community production (NCP) during emersion on sandflats was estimated to be $2.87 \mathrm{~g} \mathrm{C} \mathrm{m}^{-2} \mathrm{yr}^{-1}$, indicating an autotrophic system. However, taking into account the variation in benthic metabolism during immersion, the subtropical intertidal sandflats shifted to a heterotrophic system, and annual NCP was calculated to be $-91.47 \mathrm{~g} \mathrm{C} \mathrm{m}^{-2} \mathrm{yr}^{-1}$.
\end{abstract}

KEY WORDS: Carbon sink - Gross community production - Community respiration - Net community production $\cdot$ Sediment granulometry $\cdot$ Kaomei Wetland $\cdot$ Taiwan

\section{INTRODUCTION}

Shallow coastal waters are among the most productive natural ecosystems in the world (Schelske \& Odum 1962). However, there is still uncertainty whether primary production in coastal waters is exported or recycled (Chen \& Borges 2009). The organic carbon burial rate in vegetated habitats, including salt marshes, mangroves and seagrass beds, was estimated on a global scale to be $\sim 0.33 \mathrm{Pg}$ $\mathrm{C} \mathrm{yr}^{-1}$ (Nellemann et al. 2009). One of the most common types of coastal ecosystems is characterized by wide, nonvegetated, intertidal sandflats, in which benthic microalgae inhabit the surfaces of sediments. The role of intertidal sandflats in carbon flux has seldom been investigated (Laffoley \& Grimsditch 2009). The 'missing carbon sink' $\left(1.8 \pm 0.5 \mathrm{Pg} \mathrm{C} \mathrm{yr}^{-1}\right)$ from the global budget may be accounted for by the existence of such widespread small sinks (Schindler 1999). Smetacek (1999) indicated the need to better quantify the role of primary production of benthic microalgae in the global carbon cycle.

Benthic microalgae on intertidal flats are not the only major autochthonous source of organic matter in 
the littoral zone (Peterson \& Howarth 1987, Sullivan \& Moncrieff 1990, Antonio et al. 2010). Other sources are vascular plants, macroalgae and phytoplankton. Resuspension of benthic microalgae by tidal oscillations may also directly contribute to water column production and play a significant role in trophic dynamics (MacIntyre et al. 1996). This could generate a net carbon flux from littoral zones to open coastal basins, thus corresponding to the 'missing carbon sink' (Guarini 2008). Benthic microalgal biomass and production may equal or exceed the biomass and production of phytoplankton in the overlying water column in shallow waters (MacIntyre et al. 1996, Cahoon 1999). Barranguet et al. (1998) indicated that production of benthic microalgae in general is higher than that of phytoplankton in waters of $<1 \mathrm{~m}$ in depth.

Intertidal benthic microalgae generally comprise an assemblage of motile benthic diatoms (mainly pennate) that migrate vertically upward to the sediment surface at the beginning of the daytime emersion period and downward at its end (Serôdio et al. 1997). Guarini et al. (2000) found that this oscillatory behavior of benthic microalgal biomass on intertidal mudflats is controlled by the night/day cycle and tidal hydrodynamic forcing, in which biomass increases during diurnal emersion and decreases during immersion and nocturnal emersion. High turbidity in shallow waters, caused by tidal oscillations, limits light penetration. Because of this, primary production of benthic microalgae mostly occurs on the surface of intertidal mudflats during daytime emersion (Alpine \& Cloern 1988). Light attenuation into the sediment is so strong that primary production occurs only within a biofilm at the surface of the sediment (Guarini et al. 2000).

Benthic microalgal production has been studied in very few tropical and subtropical locations (Cahoon 1999), despite the fact that higher values of benthic microalgal production may be found in such areas. Tropical and subtropical areas feature high light fluxes and year-round production, which should drive high annual rates of primary production. Cahoon (1999) indicated that the estimation of benthic microalgal production in tropical areas is limited to only one simple measurement and does not adequately represent production in habitats other than coral reefs. The aim of this study was to determine both the temporal and spatial variability of benthic metabolism on intertidal sandflats of a subtropical coastal wetland during emersion and to examine environmental and biological factors that influence metabolism. Over a 19 mo period, in situ carbon dio- xide flux measurements at the air-sediment interface were carried out to make monthly estimates. To provide an accurate annual budget of benthic production during emersion we considered corrections for cloudiness (Migné et al. 2004), the time lag between emersion and maximum production due to vertical migration of benthic diatoms (Spilmont et al. 2007) and variations in $\mathrm{CR}$ during night-time emersion periods. In situ dissolved oxygen flux measurements during immersion were also integrated across time and space to derive an estimate of annual benthic metabolism of subtropical intertidal sandflats for both emersion and immersion conditions throughout the year.

\section{MATERIALS AND METHODS}

\section{Study site}

The Kaomei Wetland $\left(24^{\circ} 18^{\prime} \mathrm{N}, 120^{\circ} 32^{\prime} \mathrm{E}\right)$ is located south of the estuary of the Tachia River in central Taiwan (Fig. 1), and has been designated a wildlife reserve owing to its high biodiversity. The coastline of the wetland is $3.5 \mathrm{~km}$ long, and the intertidal zone is $1.8 \mathrm{~km}$ wide. The 701 ha area is mainly composed of estuary, sandflats (341 ha), small areas of salt marsh (22.3 ha) and seagrass beds (7.87 ha), and has a few mangroves scattered within the salt marshes. Tides are semidiurnal with a range of 3 to $4 \mathrm{~m}$. Climatic data derived from the local weather station at Wuchi during the period from 2008 to 2009 (Climatological Data Annual Report, Central Weather Bureau of Taiwan) show that air temperatures ranged from

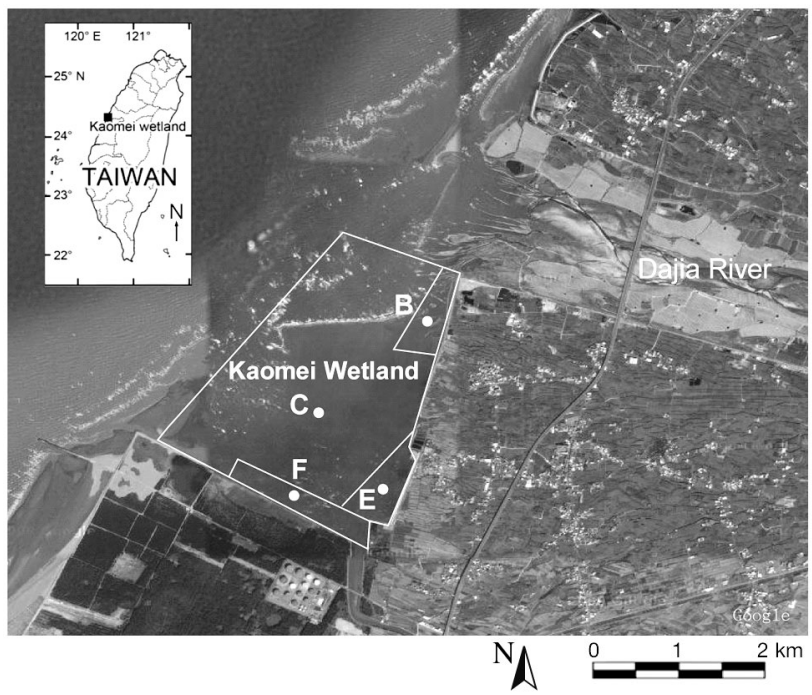

Fig. 1. Location of the study sites in the Kaomei Wetland. Map credit: Google Earth 
28 to $30^{\circ} \mathrm{C}$ in summer and 15 to $20^{\circ} \mathrm{C}$ in winter (Fig. 2). In fall and winter (the dry season, October to March), monthly rainfall normally does not exceed $40 \mathrm{~mm}$, and in spring and summer (the wet season, April to September) the monthly rainfall frequently exceeds $150 \mathrm{~mm}$. Consequently, mean water salinities are lower in the wet season (20.5) and higher in the dry season (34.5) (Hsieh \& Lin 2006). Mean salinities in sediment pore waters are also lower in the wet season (1.94) and higher in the dry season (7.71). The substrate level of intertidal sandflats was measured by comparing observed water levels overlying the intertidal sandflats and predicted water levels were derived from the tide table (Central Weather Bureau of Taiwan) during immersion. The mean $( \pm$ SE) substrate level of intertidal sandflats was $1.35 \pm 0.05 \mathrm{~m}$ above the chart datum, which is based on mean sea level as determined by a tidal gauge station at Keelung, northern Taiwan.

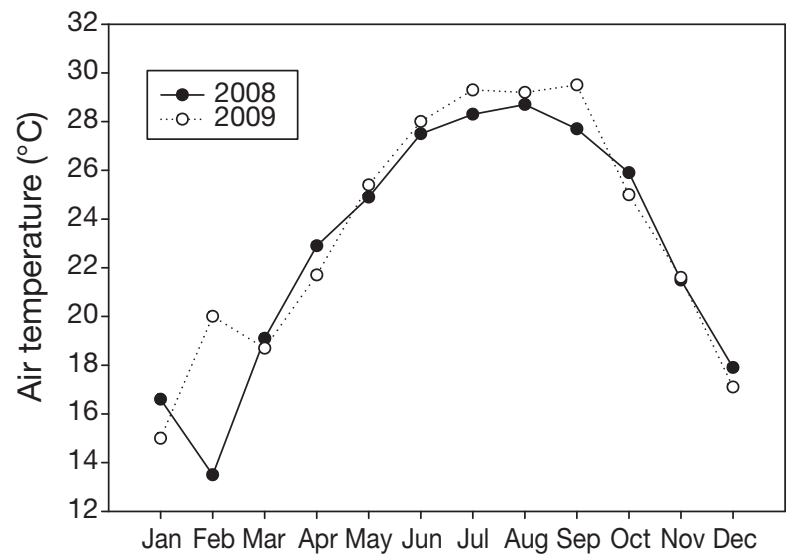

Fig. 2. Mean air temperature $\left({ }^{\circ} \mathrm{C}\right)$ recorded monthly from 2008 to 2009 in the Kaomei Wetland
The wetland's intertidal sandflats were divided into 4 regions (Fig. 1) according to vegetation type and sediment granulometry. Site B, consisting of unvegetated sandflats with medium sand sediments, was located in the north of the Kaomei Wetland near the estuary. Site $\mathrm{C}$ was located in seagrass beds of Zostera japonica with coarse sand sediments. Site E was located in an area of salt marshes that featured fine sand sediments and the marsh plant, Bolboschoenus planiculmis. Site $\mathrm{F}$ was located in the southern portion of the Kaomei Wetland and consisted of unvegetated sandflats with coarse sand sediments. Data for depth of the oxidized layer, water content and organic content of sediment were derived from Hsieh \& Lin (2006) collected in August 2005 to July 2006. At least 3 replicates were taken monthly for all samples at the 4 sites during emersion. Sediment at $15 \mathrm{~cm}$ deep from the surface was sampled with a PVC tube that had an inner diameter of $2.0 \mathrm{~cm}$. The depth of the oxidized layer was measured as the depth where redox potential exceeded $300 \mathrm{mV}$. Sediment water content was measured as the percentage of weight lost by drying at $60^{\circ} \mathrm{C}$ for $48 \mathrm{~h}$. The organic matter content of the sediment was calculated as the percentage of weight loss from dried sediment after being heated to $450^{\circ} \mathrm{C}$ for $6 \mathrm{~h}$. The oxidized layer of sediment was deeper at Sites B and C and shallower at site $\mathrm{E}$ (Table 1). The organic content and sediment water content were higher at Sites B and E and lower at Sites $\mathrm{C}$ and F.

\section{In situ benthic metabolism}

During emersion periods, $\mathrm{CO}_{2}$ fluxes at the airsediment interface were measured with a benthic chamber modified from Migné et al. (2002). The

Table 1. Sediment characteristics of 4 study sites on intertidal sandflats of the Kaomei Wetland. Values are mean \pm SD $(n=12$ per site). Data for depth of the oxidized layer, water content and organic content of sediment were derived from the study by Hsieh \& Lin (2006)

\begin{tabular}{|c|c|c|c|c|c|c|c|c|c|}
\hline Site & $\begin{array}{l}\text { Latitude, } \\
\text { longitude }\end{array}$ & Vegetation & Substrate & $\begin{array}{l}\text { Depth of } \\
\text { oxidized } \\
\text { layer }(\mathrm{cm})\end{array}$ & $\begin{array}{l}\text { Gravimetric } \\
\text { water } \\
\text { content }(\%)\end{array}$ & $\begin{array}{c}\text { Organic } \\
\text { content } \\
(\%)\end{array}$ & $\begin{array}{l}\text { Grain size } \\
\text { (mm) }\end{array}$ & $\begin{array}{l}\text { Silt/clay } \\
\text { content } \\
(\%)\end{array}$ & $\begin{array}{c}\text { Sorting } \\
\text { coefficient }\end{array}$ \\
\hline B & $\begin{array}{l}24^{\circ} 19^{\prime} 71^{\prime} \mathrm{N}, \\
120^{\circ} 33^{\prime} 61^{\prime} \mathrm{E}\end{array}$ & Un & $\begin{array}{l}\text { Medium } \\
\text { sand }\end{array}$ & $5.6 \pm 4.75$ & $28.7 \pm 6.49$ & $.38 \pm 0.17$ & $0.39 \pm 0.13$ & $28.1 \pm$ & 1.03 \\
\hline $\mathrm{C}$ & $\begin{array}{l}24^{\circ} 18^{\prime} 93^{\prime} \mathrm{N}, \\
120^{\circ} 33^{\prime} 49^{\prime} \mathrm{E}\end{array}$ & $\begin{array}{c}\text { Seagrass } \\
\text { (Zostera japonica) }\end{array}$ & $\begin{array}{l}\text { Coarse } \\
\text { sand }\end{array}$ & 20.6 & $21.2 \pm$ & $0.90 \pm 0.14$ & $0.61=$ & 8.11 & 0.78 \\
\hline $\mathrm{E}$ & $\begin{array}{l}24^{\circ} 18^{\prime} 40^{\prime} \mathrm{N}, \\
120^{\circ} 32^{\prime} 54^{\prime} \mathrm{E}\end{array}$ & $\begin{array}{c}\text { Marsh plant } \\
\text { (Bolboschoenus } \\
\text { planiculm) }\end{array}$ & Fine sand & $13 \pm 1.50$ & $28.6 \pm 9.22$ & $1.42 \pm 0.16$ & $0.22 \pm$ & $52.3 \pm$ & 0.81 \\
\hline F & $\begin{array}{l}24^{\circ} 18^{\prime} 60^{\prime} \mathrm{N}, \\
120^{\circ} 32^{\prime} 40^{\prime} \mathrm{E}\end{array}$ & Unvegetated & $\begin{array}{l}\text { Coarse } \\
\text { sand }\end{array}$ & $8.93 \pm 1.15$ & $22.5 \pm 5.08$ & $0.75 \pm 0.05$ & $0.66 \pm 0.07$ & $8.91 \pm 8.1$ & $0.73 \pm 0.13$ \\
\hline
\end{tabular}


chamber was $30 \mathrm{~cm}$ in diameter and had a semicircular upper transparent acrylic cover fitted onto a stainless steel ring. The steel ring was pushed into the sediment to a depth of $10 \mathrm{~cm}$ to enclose a $0.071 \mathrm{~m}^{2}$ surface area in the chamber; the volume of trapped air was $10.6 \mathrm{l}$. Changes in the $\mathrm{CO}_{2}$ mole fraction (ppm) of the air above the sediment were monitored with an infrared $\mathrm{CO}_{2}$ gas analyzer (Li-820, LI-COR). Data were recorded on a data logger (Li-1400, LICOR) by using a $30 \mathrm{~s}$ logging frequency. $\mathrm{CO}_{2}$ fluxes were then calculated by regressing the $\mathrm{CO}_{2}$ concentration ( $\mu \mathrm{mol} \mathrm{CO}_{2} \mathrm{~mol}^{-1}$ air) against time (min). Results were then expressed in carbon units ( $\mathrm{mg} \mathrm{C}^{-1}$ $\mathrm{m}^{-2} \mathrm{~h}^{-1}$ ), assuming a molar volume of $24.5 \mathrm{l} \mathrm{mol}^{-1}$ at $1 \mathrm{~atm}$ pressure and $25^{\circ} \mathrm{C}$ and a molar mass of $12 \mathrm{~g} \mathrm{C}$ $\mathrm{mol}^{-1} \mathrm{CO}_{2}$. Air temperatures inside and outside the chambers were monitored with the WatchDog Model 250 Data Logger (Spectrum Technologies).

Benthic metabolism was measured in situ under ambient light at 10:00 to 14:00 $\mathrm{h}$ when irradiance was at a saturation level for photosynthesis in order to estimate net community production (NCP) and in darkness (100\% shading) to estimate community respiration (CR). Gross community production (GCP) was then calculated as the difference between NCP and CR. At each site for each month, triplicate chambers were exposed in the field in sequence to 5 different irradiances of $0,30,50,70$ and $100 \%$ shading. This was done by interposing screens with different mesh sizes for measurement of photosynthesis as a function of incident irradiance on the sediment $(P-I$ curve). Each $P-I$ curve was described by Eq. (1) of Jassby \& Platt (1976):

$$
P=P_{\max } \tanh \left(\alpha E / P_{\max }\right)
$$

where $P$ refers to GCP in $\mathrm{mg} \mathrm{C} \mathrm{m}{ }^{-2} \mathrm{~h}^{-1}, P_{\max }$ is the maximum rate of GCP $\left(\mathrm{GCP}_{\mathrm{m}}\right)$ in the absence of photoinhibition under optimal irradiance, $\alpha$ is the initial slope of the line under low irradiance when photosynthesis is assumed to be proportional to photon density and $E$ is the irradiance measured as photosynthetically active radiation (PAR) in $\mu$ mol photons $\mathrm{m}^{-2} \mathrm{~s}^{-1}$. Incident PAR on the sediment was continuously measured in situ at 5 min intervals with a Li189 meter (LI-COR) from early morning $(07: 00 \mathrm{~h})$ until after sunset (19:00 h). The parameter $\alpha$ indicates the efficiency with which incident PAR is converted into photosynthetic production by the algal community. $\mathrm{GCP}_{\mathrm{m}}$ can also be interpreted as the photosynthesis capacity. We used SigmaPlot (v. 8.02, SPSS) for nonlinear regression fitting and considered results acceptable when the fit was significant $(p<0.05)$ and the power of the performed test was $>0.80$.

\section{Annual budget of potential production}

In situ benthic metabolism was measured on a monthly basis at the 4 study sites on intertidal sandflats from June 2008 to December 2009. Daily GCP was calculated as a function of the incident PAR and light duration during emersion periods by using the $P$-I curve for each day of the month. Emersion time data for each day were obtained from the local tidal gauge station at Wuchi during the period from 2008 to 2009 (Tidal Table, Central Weather Bureau of Taiwan). Light duration was corrected for cloudiness according to sunshine duration data (h) recorded at Wuchi during 2008 to 2009 (Climatological Data Annual Report, Central Weather Bureau of Taiwan). The progressive increase (or decrease) in GCP as a linear variation at the beginning of exposure (or just before flooding) was also included in the calculation by using the correction formula describing the effects of vertical migration of benthic diatoms (Spilmont et al. 2007):

$$
\mathrm{TL}_{\mathrm{GCP} / \mathrm{em}}=0.52\left(\mathrm{TL}_{\mathrm{em} / \mathrm{noon}}\right)+37.52
$$

where $\mathrm{TL}_{\mathrm{GCP} / \mathrm{em}}$ is the time lag in minutes between $\mathrm{GCP}_{\mathrm{m}}$ and emersion time, and $\mathrm{TL}_{\mathrm{em} / \text { noon }}$ is the time lag between emersion time and local noon. For each day of the month, $\mathrm{TL}_{\mathrm{GCP} / \mathrm{em}}$ values were calculated as a function of $\mathrm{TL}_{\mathrm{em} / \mathrm{noon}}$. $\mathrm{TL}_{\mathrm{GCP} / \mathrm{em}}$ values were then deducted from light duration during emersion time after $\mathrm{GCP}_{\mathrm{m}}$ was reached for the calculation of daily GCP. Daily GCP was integrated to estimate monthly GCP during emersion, and annual GCP at each site was estimated by gathering monthly GCP data over a 19 mo period. This was then integrated across the entire sandflat habitat based on each region's areal proportion $(10 \%$ at $\mathrm{B}, 70 \%$ at $\mathrm{C}, 10 \%$ at $\mathrm{E}$, and $10 \%$ at F) and expanded to estimate annual potential production in the sandflats during emersion.

In order to incorporate variations in $\mathrm{CR}$ during nighttime periods, respiration rates during daytime and nighttime emersion periods were measured in August 2010 at Sites E and F. The mean ratio between respiration rates during daytime and nighttime periods was used to estimate nighttime respiration rates during emersion across the 4 study sites throughout the year.

To integrate benthic metabolism throughout a tidal cycle, in situ $\mathrm{O}_{2}$ fluxes at the water-sediment interface were also measured during immersion by using a core incubation technique at the 4 study sites on intertidal sandflats in January (winter) and June 2006 (summer). The incubated cores were manipulated to simulate the field condition during immersion. In situ measurements were performed for the water column 
only and for sediment plus water column $(\mathrm{n}=6$ for each treatment) in outdoor tanks with flow-through water. The water column core was used to correct the dissolved oxygen measurements in the sediment plus water column core. For the sediment plus water column core, sediment cores measuring $10 \mathrm{~cm}$ long were manually collected in acrylic tubes $(7 \mathrm{~cm}$ in diameter, $30 \mathrm{~cm}$ long) during immersion (in about $50 \mathrm{~cm}$ of water). Therefore, the sediment plus water column core also contained $20 \mathrm{~cm}$ of water depth overlying the sediment. When conducting core incubations, 6 cores were arranged in a row within an acrylic tank, and the distance between the cores was at least $10 \mathrm{~cm}$ to avoid shading caused by neighboring cores. Three replicate cores within each tank in random order were incubated for the water column only, while the other 3 were for the sediment and water column. Flowing water outside the cores was used to maintain temperatures at ambient levels and did not mix with the water inside the cores. Incubations were conducted beside the Kaomei Wetland from 10:00 to 14:00 h when irradiance was saturated for photosynthesis. At each site for each season, triplicate cores were exposed in the field to 5 different irradiances of $0,30,50,70$ and $100 \%$ shading by interposing screens with different mesh sizes. Dark cores with $100 \%$ shading were tightly wrapped in aluminum foil for complete exclusion of irradiance to determine benthic CR. Water samples were collected by means of a peristaltic pump at the start of incubation and then at the end of the 2 to $3 \mathrm{~h}$ incubation. Dissolved oxygen (DO) concentrations were monitored with a DO meter (YSI Model 52, Yellow Springs Instruments) immediately after sampling. Benthic $\mathrm{NCP}$ and $\mathrm{CR}\left(\mathrm{mmol} \mathrm{O}_{2} \mathrm{~m}^{-2} \mathrm{~h}^{-1}\right)$ were derived from changes in DO concentrations over time. Benthic GCP was calculated as the difference between the benthic NCP and CR. The mean value of benthic GCP at each irradiance level $(\mathrm{n}=3)$ was then used to fit the $P-I$ curve described by Eq. (1) of Jassby \& Platt (1976). Daily benthic GCP was calculated as a function of the incident PAR and light duration during immersion by using the $P-I$ curve for winter or summer. Immersion time data for each day were obtained from the local tidal gauge station at Wuchi during 2008 and 2009 (Tidal Table, Central Weather Bureau of Taiwan). Light duration was also corrected for cloudiness according to the sunshine duration data (h) recorded at Wuchi during 2008 and 2009 (Climatological Data Annual Report, Central Weather Bureau of Taiwan). We used a photosynthetic quotient of 1.2 to convert $\mathrm{O}_{2}$ fluxes into $\mathrm{CO}_{2}$ fluxes for integration (Meyercordt \& Meyer-Reil 1999).

\section{Sediment chlorophyll a concentration and macrofaunal biomass}

After performing in situ measurements of benthic metabolism, benthic microalgae and macrofauna were collected to estimate the biomass present in the benthic chambers. Plastic cores $(n=6)$ with capacity of $2.5 \mathrm{ml}$ and an inner diameter of $1.0 \mathrm{~cm}$ were pushed into the sediment under the chamber down to a depth of $1 \mathrm{~cm}$ and then stored in a cool box until samples were taken back to the laboratory. In the lab, each sample was soaked in $95 \%$ acetone for overnight extraction in the dark at $4^{\circ} \mathrm{C}$. The chlorophyll a (chl a) concentration in the supernatant was measured by spectrophotometry (Parsons et al. 1984) and expressed in terms of weight of chl a per unit surface area $\left(\mathrm{mg} \mathrm{m}^{-2}\right)$.

Macrofauna were sampled in triplicate from March to December 2009 by pushing a stainless steel ring corer (10 cm inner diameter) into the sediment under the chamber to a depth of $10 \mathrm{~cm}$. Samples were strained with a $0.5 \mathrm{~mm}$ sieve, preserved in $70 \%$ ethanol, and then brought back to the laboratory for classification, counting and weighing. Macrofauna were identified to the lowest possible taxonomic level and counted by means of a stereomicroscope in the laboratory. Biomass was expressed as wet weight (WW) per unit surface area $\left(\mathrm{g} \mathrm{WW} \mathrm{m}^{-2}\right)$.

\section{Sediment granulometry}

Sediment grain size was assessed at each site from February to December 2009. Samples were collected with a PVC corer that had a $2.6 \mathrm{~cm}$ inside diameter, and sediments $5 \mathrm{~cm}$ deep from the surface were taken for further measurements. Grain size, silt/clay content and sorting coefficient of sediments were determined following methods for granulometry described by Hsieh (1995).

\section{Statistical analysis}

To analyze seasonal effects (Fig. 2), data on benthic metabolism and biotic and environmental factors were divided into 4 seasons based on recorded air temperature: spring (22 to $26^{\circ} \mathrm{C}$, April and May), summer (28 to $30^{\circ} \mathrm{C}$, June through September), fall (22 to $26^{\circ} \mathrm{C}$, October and November), and winter (15 to $20^{\circ} \mathrm{C}$, December through March). In the tropical/ subtropical zone, spring and fall are transition periods between summer and winter and are relatively 
short (about 1 to 2 mo). A 2-way fixed-factor ANOVA model was used to determine whether benthic $\mathrm{GCP}_{\mathrm{m}}, \mathrm{CR}$ and other biotic and environmental factors differed among the 4 study sites (Sites B, C, E and F) and 4 seasons (spring, summer, fall, and winter). Before the analysis, values of benthic $\mathrm{CR}$, sediment chl a concentration, macrofaunal biomass and silt/clay content were fourth root transformed, and values of $\mathrm{GCP}_{\mathrm{m}}$, grain size and sorting coefficient were $\log$ transformed to conform to normality and homogeneity of variance assumptions (Clarke \& Warwick 1994). If the results of the ANOVA indicated significant main effects at the 0.05 probability level, then Fisher's protected least significant difference (LSD) test was used to determine which means significantly differed. Relationships of $\mathrm{GCP}_{\mathrm{m}}$ and $\mathrm{CR}$ with biotic and environmental factors were determined by using Pearson correlations. ANOVA and Fisher's LSD tests were conducted with the software package SPSS v. 10.0.

The effects of temperature on $\mathrm{GCP}_{\mathrm{m}}$ and CR were quantified by calculating the apparent activation energy $\left(E_{\mathrm{a}}\right.$, in $\left.\mathrm{kJ} \mathrm{mol}^{-1}\right)$ and the corresponding $Q_{10}$ value for each site according to Hancke \& Glud (2004). $E_{\mathrm{a}}$ was calculated as the slope of available data points from the initial linear part of an Arrhenius plot (temperature < optimum), where $\ln (k)$ was plotted as a function of temperature $(R T)^{-1}$ as:

$$
\ln (k)=\ln (A)+\left[-E_{\mathrm{a}} \times(R T)^{-1}\right]
$$

where $k$ is the rate of the reaction, $A$ is the Arrhenius constant, $R$ is the gas constant $\left(8.3144 \mathrm{~J} \mathrm{~K}^{-1} \mathrm{~mol}^{-1}\right)$, and $T$ is the absolute temperature (K). Ea is the overall temperature response of $\mathrm{GCP}_{\mathrm{m}}$ or $\mathrm{CR}$ within the entire sediment community. The $Q_{10}$ value was calculated from Eq. (4) as:

$$
\begin{gathered}
Q_{10}= \\
\exp \left\{E_{\mathrm{a}} \times 10 \times[R T \times(T+10)]^{-1}\right\}
\end{gathered}
$$

where $E_{\mathrm{a}}$ quantifies the increase of the reaction rate. A temperature interval of 0 to $10^{\circ} \mathrm{C}$ was used in the calculation of $Q_{10}$ according to Hancke \& Glud (2004). Because sediment surface temperature was variable depending upon the exposure time, air temperature was used in this study.

\section{RESULTS}

\section{Sediment granulometry}

There were no significant seasonal differences in measured abiotic variables of sediments. However, spatial variations in sediment granulometry were clear (Table 2). The silt/clay content of sediment was higher at Site E and lower at Sites C and F (Table 1). Conversely, sediment grain size was greater at Sites $\mathrm{F}$ and $\mathrm{C}$ and smaller at Site E. The sorting coefficient of sediment was higher at Site B, indicating that it was relatively poorly sorted. The silt/clay content and sorting coefficient of sediment were negatively correlated with grain size.

\section{Sediment chl a concentration and macrofaunal biomass}

There were no significant differences in sediment chl a concentrations and macrofaunal biomass among sites and seasons (Table 2). The mean sediment chl a concentration was highest at Site E in Sep-

Table 2. Results of 2-way ANOVA of benthic primary production and respiration, sediment chl a concentration, macrofaunal biomass and abiotic variables among seasons and 4 study sites on intertidal sandflats of the Kaomei Wetland $(\mathrm{p}<0.05)$. Means for seasons and sites (under Separation) with the same

\begin{tabular}{|c|c|c|c|c|c|}
\hline Variable & Factor & $\mathrm{df}$ & $F$ & $\mathrm{p}$ & Separation \\
\hline $\begin{array}{l}\text { Maximum gross } \\
\text { community pro- } \\
\text { duction }\left(\mathrm{GCP}_{\mathrm{m}}\right)\end{array}$ & $\begin{array}{c}\text { Season } \\
\text { Site } \\
\text { Season } \times \text { site }\end{array}$ & $\begin{array}{l}3 \\
3 \\
9\end{array}$ & $\begin{array}{l}4.96 \\
2.36 \\
1.57\end{array}$ & $\begin{array}{l}0.004 \\
0.081 \\
0.147\end{array}$ & $\begin{array}{r}\operatorname{sum}^{\mathrm{a}}, \mathrm{fal}^{\mathrm{a}}, \mathrm{win}^{\mathrm{b}}, \mathrm{spr}^{\mathrm{b}} \\
\mathrm{F}^{\mathrm{a}}, \mathrm{B}^{\mathrm{ab}}, \mathrm{C}^{\mathrm{ab}}, \mathrm{E}^{\mathrm{b}}\end{array}$ \\
\hline $\begin{array}{l}\text { Community } \\
\text { respiration (CR) }\end{array}$ & $\begin{array}{c}\text { Season } \\
\text { Site } \\
\text { Season } \times \text { site }\end{array}$ & $\begin{array}{l}3 \\
3 \\
9\end{array}$ & $\begin{array}{r}6.75 \\
10.20 \\
0.81\end{array}$ & $\begin{array}{l}0.001 \\
0.042 \\
0.603\end{array}$ & $\begin{array}{c}\operatorname{sum}^{\mathrm{a}}, \mathrm{fal}^{\mathrm{b}}, \text { win }^{\mathrm{b}}, \mathrm{spr}^{\mathrm{b}} \\
\mathrm{B}^{\mathrm{a}}, \mathrm{F}^{\mathrm{b}}, \mathrm{E}^{\mathrm{b}}, \mathrm{C}^{\mathrm{b}}\end{array}$ \\
\hline $\begin{array}{l}\text { Sediment chl a } \\
\text { concentration }\end{array}$ & $\begin{array}{c}\text { Season } \\
\text { Site } \\
\text { Season } \times \text { site }\end{array}$ & $\begin{array}{l}3 \\
3 \\
9\end{array}$ & $\begin{array}{l}1.24 \\
2.10 \\
0.69\end{array}$ & $\begin{array}{l}0.302 \\
0.110 \\
0.707\end{array}$ & \\
\hline $\begin{array}{l}\text { Macrofaunal } \\
\text { biomass }\end{array}$ & $\begin{array}{c}\text { Season } \\
\text { Site } \\
\text { Season } \times \text { site }\end{array}$ & $\begin{array}{l}3 \\
3 \\
9\end{array}$ & $\begin{array}{l}0.63 \\
0.95 \\
0.82\end{array}$ & $\begin{array}{l}0.615 \\
0.433 \\
0.601\end{array}$ & \\
\hline Grain size (mm) & $\begin{array}{c}\text { Season } \\
\text { Site } \\
\text { Season } \times \text { site }\end{array}$ & $\begin{array}{l}3 \\
3 \\
9\end{array}$ & $\begin{array}{r}0.30 \\
10.37 \\
0.49\end{array}$ & $\begin{array}{r}0.823 \\
<0.001 \\
0.865\end{array}$ & $\mathrm{~F}^{\mathrm{a}}, \mathrm{C}^{\mathrm{a}}, \mathrm{B}^{\mathrm{b}}, \mathrm{E}^{\mathrm{c}}$ \\
\hline $\begin{array}{l}\text { Silt/clay } \\
\text { content (\%) }\end{array}$ & $\begin{array}{c}\text { Season } \\
\text { Site } \\
\text { Season } \times \text { site }\end{array}$ & $\begin{array}{l}3 \\
3 \\
9\end{array}$ & $\begin{array}{r}0.95 \\
20.27 \\
0.97\end{array}$ & $\begin{array}{r}0.430 \\
<0.001 \\
0.485\end{array}$ & $\mathrm{E}^{\mathrm{a}}, \mathrm{B}^{\mathrm{b}}, \mathrm{C}^{\mathrm{c}}, \mathrm{F}^{\mathrm{c}}$ \\
\hline Sorting coefficient & $\begin{array}{c}\text { Season } \\
\text { Site } \\
\text { Season } \times \text { site }\end{array}$ & $\begin{array}{l}3 \\
3 \\
9\end{array}$ & $\begin{array}{l}0.11 \\
4.64 \\
0.34\end{array}$ & $\begin{array}{l}0.948 \\
0.010 \\
0.951\end{array}$ & $\mathrm{~B}^{\mathrm{a}}, \mathrm{E}^{\mathrm{b}}, \mathrm{C}^{\mathrm{b}}, \mathrm{F}^{\mathrm{b}}$ \\
\hline
\end{tabular}
superscript letters do not significantly differ. spr: spring; sum: summer; fal: fall; win: winter 
tember 2008 (99.71 $\mathrm{mg} \mathrm{m}^{-2}$, Fig. 3) and lowest at Site B in August $2009\left(1.92 \mathrm{mg} \mathrm{m}^{-2}\right)$. The sediment $\mathrm{chl} a$ concentration was positively correlated with macrofaunal biomass (Table 3) and exhibited a marginally positive correlation with the sediment silt/clay content $(p=0.066)$.

The biomass of intertidal sandflats macrofauna was dominated by bivalves and decapods (Table 4). While Site B near the estuary was dominated by bivalves, other sites were dominated by decapods. However, amphipods were the most numerically dominant group across all sites. An extremely high biomass of the duck lantern clam Laternula anatina occurred at Site B in July 2009 (Fig. 4). Macrofaunal biomass showed a positive correlation with the sediment silt/clay content and a marginally negative correlation ( $p=0.081$ ) with grain size (Table 3).

\section{In situ benthic metabolism during emersion}

$P$ - $I$ curves obtained at the 4 study sites on intertidal sandflats during emersion in December 2008 (winter), April 2009 (spring), September 2009 (summer) and November 2009 (fall) are shown as examples (Fig. 5). Across all 4 study sites, these $P$ - $I$ curves showed a higher photosynthesis capacity $\left(\mathrm{GCP}_{\mathrm{m}}\right)$ and higher photosynthesis efficiency $(\alpha)$ in summer and fall than in the other seasons. In addition, values of $\mathrm{GCP}_{\mathrm{m}}$ and $\alpha$ in summer and fall were higher at Site $\mathrm{C}$ and lower at Site E.

During emersion, $\mathrm{GCP}_{\mathrm{m}}$ measurements derived from the $P$ - $I$ curves showed a clear seasonal pattern, with significantly higher values in summer and fall and lower values in spring and winter (Fig. 6). $\mathrm{GCP}_{\mathrm{m}}$ was positively correlated with air temperature (Table 3). GCP $\mathrm{m}$ also showed clear spatial variations. Values were significantly higher at Site F and lower at Site E (Table 2). The highest mean

Table 3. Pearson correlation coefficients (r) relating benthic primary production and respiration, sediment chl a concentration, macrofauna biomass and abiotic variables on intertidal sandflats at 4 study sites in the Kaomei Wetland. $\mathrm{GCP}_{\mathrm{m}}$ : maximum gross community production; CR: community respiration. Significant correlations are given in bold text. ${ }^{* * *} \mathrm{p}<0.001,{ }^{* *} \mathrm{p}<0.01,{ }^{*} \mathrm{p}<0.05$

\begin{tabular}{|lccccc|}
\hline Variable & & $\mathrm{GCP}_{\mathrm{m}}$ & $\mathrm{CR}$ & $\begin{array}{c}\text { Sediment chl a } \\
\text { concentration }\end{array}$ & $\begin{array}{c}\text { Macrofaunal } \\
\text { biomass }\end{array}$ \\
\hline Sediment chl a & $\mathrm{r}$ & 0.203 & $\mathbf{0 . 4 1 9 * *}$ & & \\
concentration & $\mathrm{p}$ & 0.089 & $\mathbf{< . 0 0 1}$ & & \\
Macrofaunal & $\mathrm{r}$ & -0.121 & $\mathbf{0 . 8 8 7 * * *}$ & $\mathbf{0 . 5 4 6}$ & \\
biomass & $\mathrm{p}$ & 0.474 & $\mathbf{2 . 0 0 1}$ & $<\mathbf{0 . 0 0 1}$ & \\
Air temperature & $\mathrm{r}$ & $\mathbf{0 . 3 7 9 *}$ & $\mathbf{0 . 3 7 7 ^ { * }}$ & 0.006 & 0.170 \\
& $\mathrm{p}$ & $\mathbf{0 . 0 1 4}$ & $\mathbf{0 . 0 1 4}$ & 0.968 & 0.307 \\
Grain size (mm) & $\mathrm{r}$ & 0.288 & -0.149 & -0.275 & -0.166 \\
& $\mathrm{p}$ & 0.067 & 0.350 & 0.077 & 0.318 \\
Silt/clay (\%) & $\mathrm{r}$ & $-\mathbf{0 . 3 0 9 *}$ & 0.123 & $\mathbf{0 . 3 3 3}$ & 0.148 \\
& $\mathrm{p}$ & $\mathbf{0 . 0 4 9}$ & 0.443 & $\mathbf{0 . 0 3 0}$ & 0.374 \\
Sorting & $\mathrm{r}$ & -0.243 & $\mathbf{0 . 3 1 7 *}$ & 0.139 & 0.293 \\
coefficient & $\mathrm{p}$ & 0.126 & $\mathbf{0 . 0 4 3}$ & 0.378 & 0.074 \\
\hline
\end{tabular}

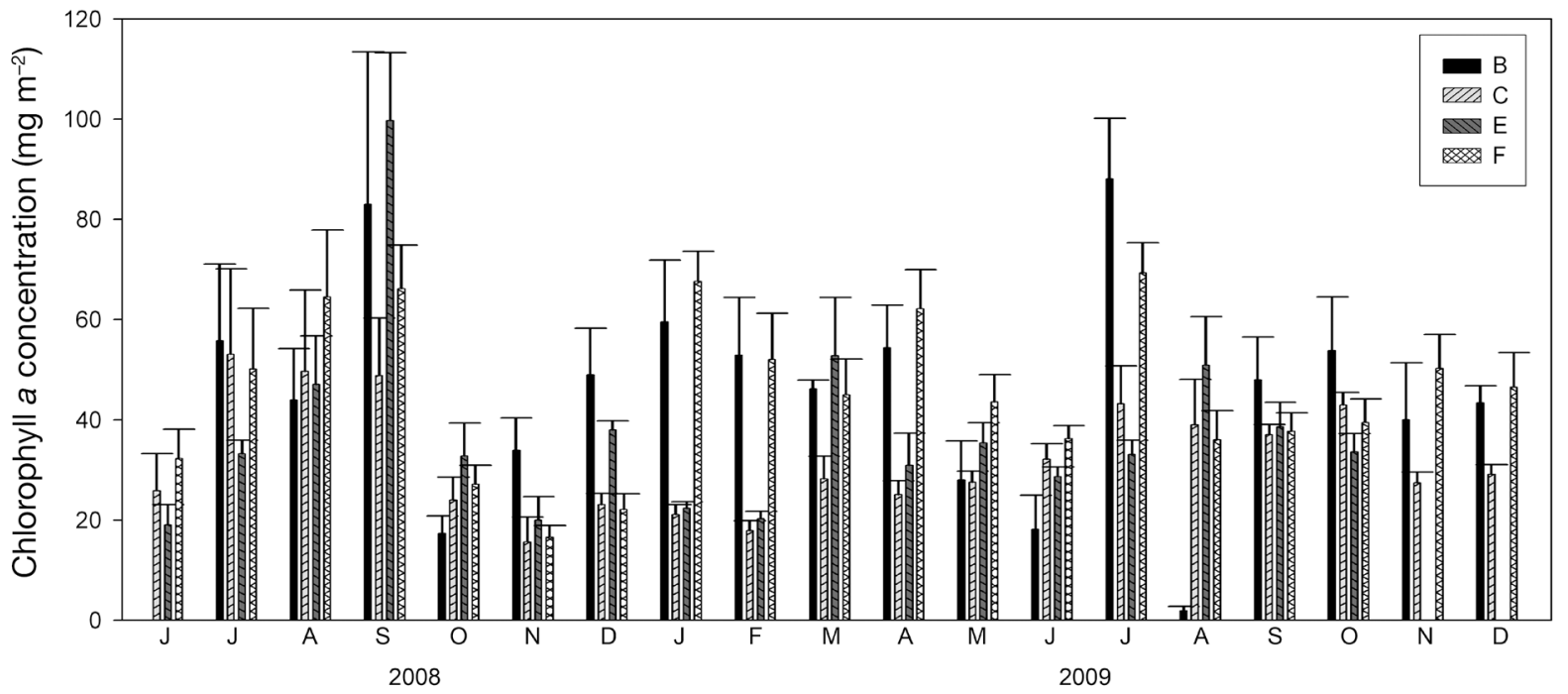

Fig. 3. Monthly changes (mean $\pm \mathrm{SD}, \mathrm{n}=3$ ) in sediment chl a concentration $\left(\mathrm{mg} \mathrm{m}^{-2}\right.$ ) on intertidal sandflats at the 4 study sites on in the Kaomei Wetland 
Table 4. Seasonal variations in mean density $\left(\mathrm{N}\right.$, ind $\left.\mathrm{cm}^{-2}\right)$ and biomass $\left(\mathrm{B}, \mathrm{mg} \mathrm{WW} \mathrm{\textrm {cm } ^ { - 2 }}\right.$ ) of macrofauna on intertidal sandflats at 4 study sites in the Kaomei Wetland

\begin{tabular}{|c|c|c|c|c|c|c|}
\hline Site & Season & & Bivalvia & Decapoda & Amphipoda & Polychaeta \\
\hline \multirow[t]{8}{*}{ B } & Spring & $\mathrm{N}$ & 0.165 & 0.010 & 0.820 & 0.010 \\
\hline & & B & 1.055 & 0.195 & 0.040 & 0.030 \\
\hline & Summer & $\mathrm{N}$ & 0.078 & 0.013 & 0.030 & \\
\hline & & B & 10.97 & 0.703 & 0.005 & \\
\hline & Fall & $\mathrm{N}$ & 0.005 & & 0.010 & 0.005 \\
\hline & & $\mathrm{B}$ & 0.005 & & 0.005 & 0.010 \\
\hline & Winter & $\mathrm{N}$ & 0.125 & & 0.535 & \\
\hline & & B & 0.370 & & 0.035 & \\
\hline \multirow[t]{8}{*}{$\mathrm{C}$} & Spring & $\mathrm{N}$ & 0.010 & 0.070 & 0.370 & 0.015 \\
\hline & & $\mathrm{B}$ & 0.035 & 5.935 & 0.050 & 0.020 \\
\hline & Summer & $\mathrm{N}$ & 0.008 & 0.060 & 0.205 & \\
\hline & & B & 0.203 & 3.375 & 0.025 & \\
\hline & Fall & $\mathrm{N}$ & 0.005 & 0.030 & 0.075 & 0.005 \\
\hline & & $\mathrm{B}$ & 0.155 & 4.355 & 0.030 & 0.001 \\
\hline & Winter & $\mathrm{N}$ & & 0.015 & 0.045 & 0.020 \\
\hline & & B & & 2.670 & 0.006 & 0.018 \\
\hline \multirow[t]{8}{*}{ E } & Spring & $\mathrm{N}$ & 0.010 & 0.050 & 0.265 & \\
\hline & & B & 0.020 & 2.350 & 0.011 & \\
\hline & Summer & $\mathrm{N}$ & 0.005 & 0.005 & 0.218 & 0.003 \\
\hline & & $\mathrm{B}$ & 0.188 & 1.180 & 0.010 & 0.018 \\
\hline & Fall & $\mathrm{N}$ & 0.005 & 0.005 & 0.060 & \\
\hline & & B & 1.600 & 0.020 & 0.005 & \\
\hline & Winter & $\mathrm{N}$ & & & 0.495 & \\
\hline & & B & & & 0.020 & \\
\hline \multirow[t]{8}{*}{$\mathrm{F}$} & Spring & $\mathrm{N}$ & 0.010 & 0.010 & 0.280 & 0.035 \\
\hline & & B & 0.030 & 0.020 & 0.060 & 0.145 \\
\hline & Summer & $\mathrm{N}$ & 0.005 & 0.018 & 0.115 & 0.008 \\
\hline & & B & 0.158 & 1.133 & 0.025 & 0.020 \\
\hline & Fall & $\mathrm{N}$ & 0.010 & 0.010 & 0.005 & \\
\hline & & B & 0.460 & 2.095 & 0.001 & \\
\hline & Winter & $\mathrm{N}$ & & & 0.265 & 0.005 \\
\hline & & B & & & 0.050 & 0.280 \\
\hline
\end{tabular}

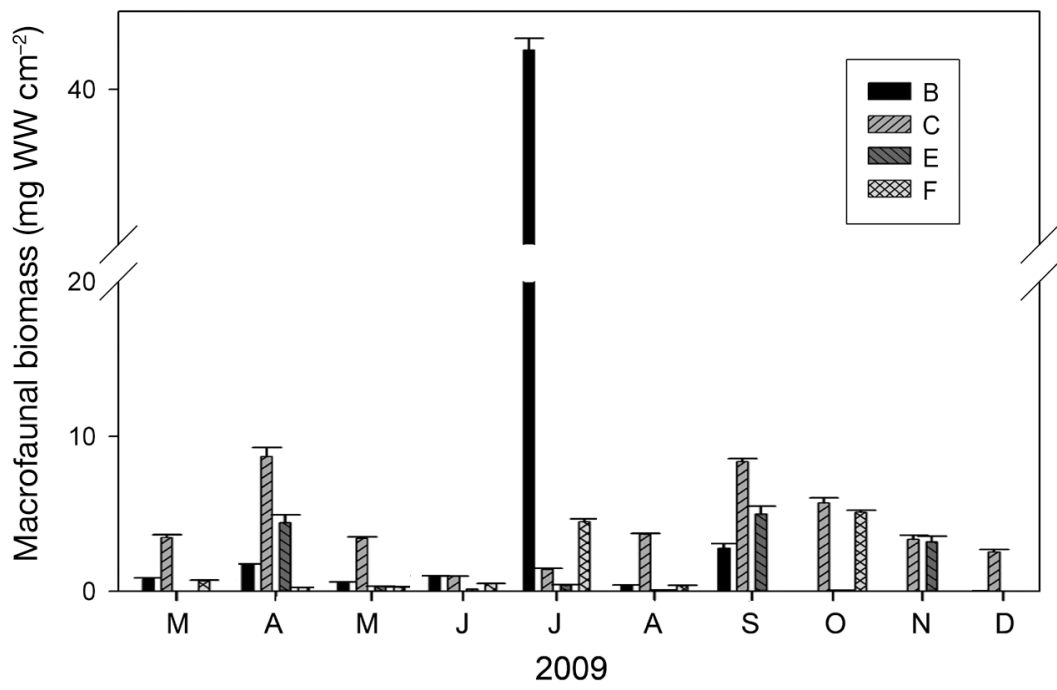

Fig. 4. Monthly changes (mean $\pm \mathrm{SD}, \mathrm{n}=3$ ) in macrofaunal biomass (mg WW $\mathrm{cm}^{-2}$ ) on intertidal sandflats at the 4 study sites in the Kaomei Wetland
$\mathrm{GCP}_{\mathrm{m}}$ occurred at Site $\mathrm{F}$ in August 2009 (78.91 $\mathrm{mg} \mathrm{C} \mathrm{m}^{-2} \mathrm{~h}^{-1}$ ), a value 3times higher than in September 2008 at the same site $\left(29.64 \mathrm{mg} \mathrm{C} \mathrm{m}^{-2} \mathrm{~h}^{-1}\right)$ (Fig. 6). The lowest mean $\mathrm{GCP}_{\mathrm{m}}$ occurred at Site B in June 2009 (0.91 $\mathrm{mg} \mathrm{C} \mathrm{m} \mathrm{m}^{-2} \mathrm{~h}^{-1}$ ). $\mathrm{GCP}_{\mathrm{m}}$ was marginally positively correlated with sediment grain size ( $p=0.067)$ and negatively correlated with the silt/clay content (Table 3).

CR also showed a clear seasonal pattern (Fig. 7). These values were significantly higher in summer and lower in winter and spring (Table 2). Site B showed significantly higher CR than other sites. The highest mean CR value (29.84 $\mathrm{mg} \mathrm{C} \mathrm{m}^{-2} \mathrm{~h}^{-1}$ ) occurred at Site B in July 2009, while the lowest mean value was measured at Site $\mathrm{F}$ in February 2009 (0.20 mg C m $\mathrm{m}^{-2} \mathrm{~h}^{-1}$ ). CR was positively correlated with air temperature, sediment sorting coefficient, sediment chl a concentration and macrofaunal biomass (Table 3 ).

The effect of temperature was further tested on $\mathrm{GCP}_{\mathrm{m}}$ and CR. Significant exponential curves were observed except for $\mathrm{GCP}_{\mathrm{m}}$ measured at Site B, the data from which did not fit the curves (Table 5). Temperature coefficients $\left(Q_{10}\right)$ were higher for CR than for $\mathrm{GCP}_{\mathrm{m}}$. Moreover, $Q_{10}$ values of $\mathrm{GCP}_{\mathrm{m}}$ and $\mathrm{CR}$ were higher at Site $\mathrm{F}$ than at the other sites. Based on each region's areal proportion, mean $Q_{10}$ values of $\mathrm{GCP}_{\mathrm{m}}$ and $\mathrm{CR}$ on the subtropical intertidal sandflats were 3.72 and 4.80 , respectively.

\section{Annual budget of potential production during emersion}

Calculated monthly GCP on intertidal sandflats during emersion also showed a clear seasonal pattern. These values were higher in summer and lower in winter and spring (Fig. 8a). The highest value was recorded in August 2009 (3.03 g C m $\mathrm{mo}^{-1}$ ) and the lowest value in February 2009 (0.23 $\left.\mathrm{g} \mathrm{C} \mathrm{m}^{-2} \mathrm{mo}^{-1}\right)$. Annual 


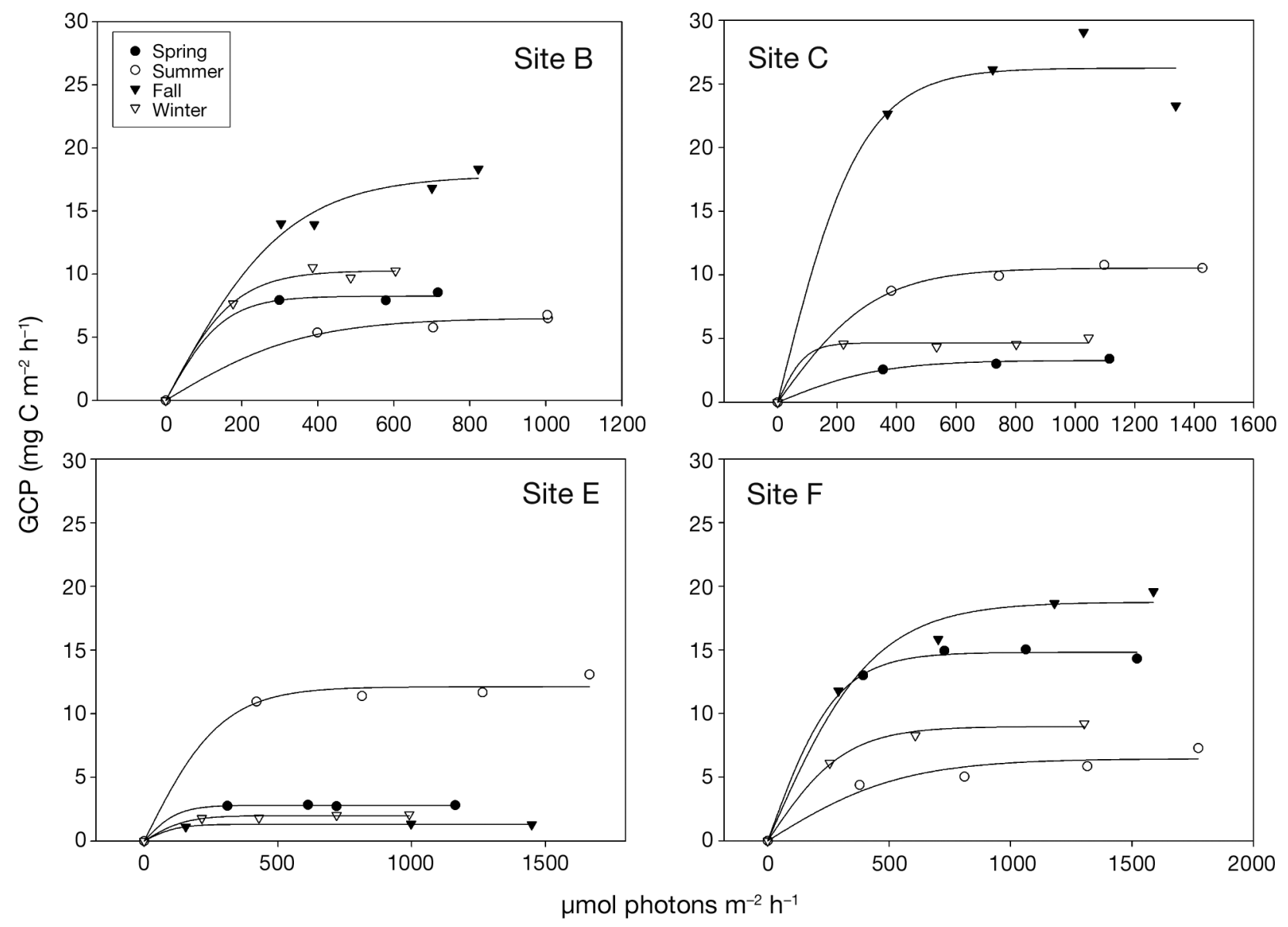

Fig. 5. Photosynthesis-irradiance $(P-I)$ curves on intertidal sandflats during emersion in December 2008 (winter), April 2009 (spring), September 2009 (summer) and November 2009 (fall) at the 4 study sites of the Kaomei Wetland

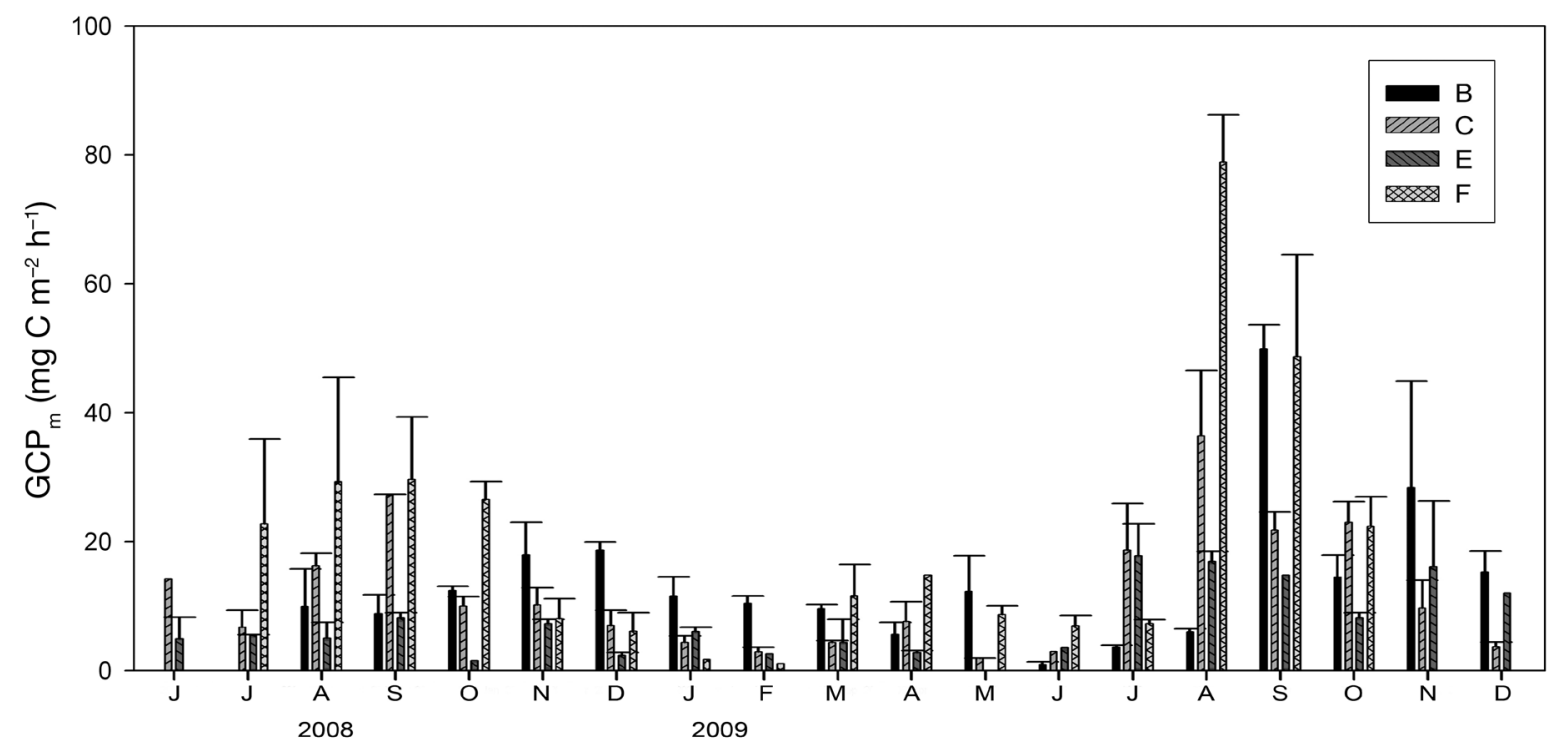

Fig. 6. Monthly changes (mean $\pm \mathrm{SD}, \mathrm{n}=3$ ) in maximum gross community production $\left(\mathrm{GCP}_{\mathrm{m}}, \mathrm{mg} \mathrm{C} \mathrm{m}^{-2} \mathrm{~h}^{-1}\right)$ on intertidal sandflats during emersion at the 4 study sites in the Kaomei Wetland 


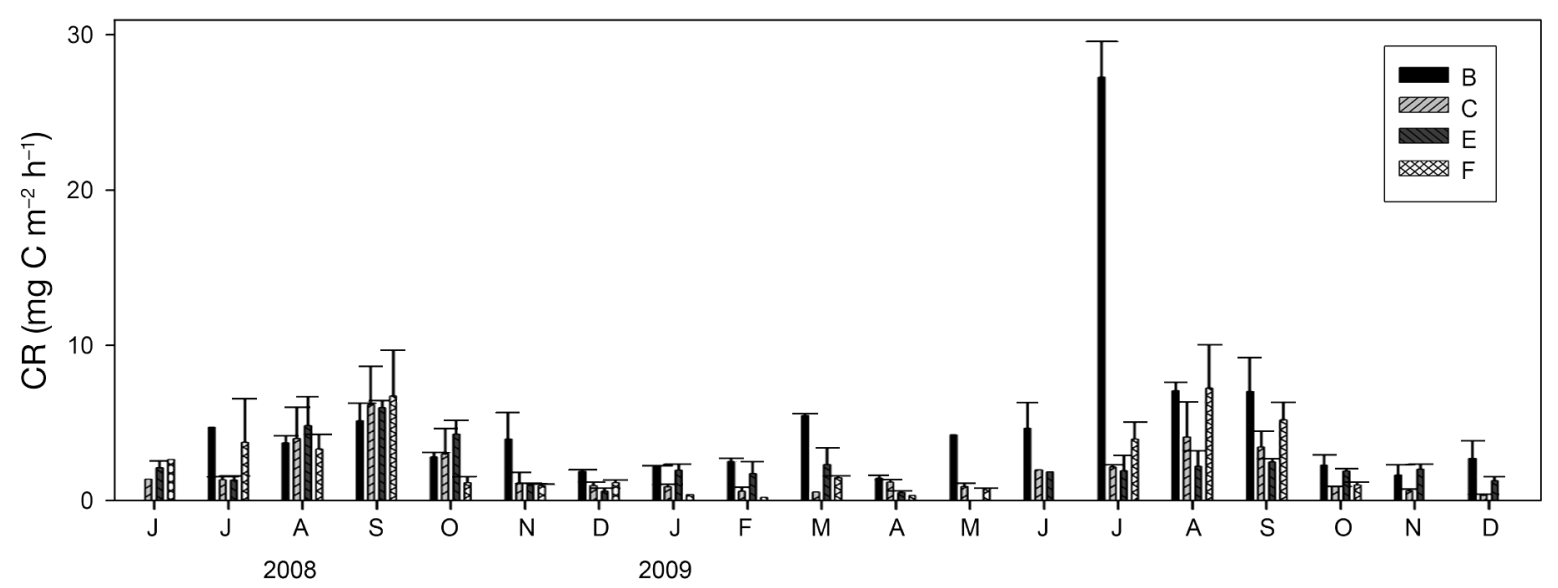

Fig. 7. Monthly changes (mean $\pm \mathrm{SD}, \mathrm{n}=3$ ) in community respiration $\left(\mathrm{CR}, \mathrm{mg} \mathrm{C} \mathrm{m} \mathrm{C}^{-2} \mathrm{~h}^{-1}\right.$ ) on intertidal sandflats during emersion at the 4 study sites in the Kaomei Wetland

Table 5. Benthic metabolism temperature response curve parameters calculated from nonlinear regression by using an Arrhenius plot for 4 study sites on intertidal sandflats of the Kaomei Wetland. $\mathrm{GCP}_{\mathrm{m}}$ : maximum gross community production; CR: community respiration; $A$ : the Arrhenius constant; $E_{\mathrm{a}}$ : apparent activation energy $\left(\mathrm{kJ} \mathrm{mol}^{-1}\right) ; \mathrm{R}_{\mathrm{a}}^{2}$ : adjusted $\mathrm{R}^{2}$; $\mathrm{n}$ : number of couple values; $Q_{10}$ : metabolism response to a $10^{\circ} \mathrm{C}$ rise of temperature. ${ }^{*} \mathrm{p}<0.05,{ }^{* *} \mathrm{p}<0.01$, ${ }^{* * *} \mathrm{p}<0.001$

\begin{tabular}{|lcrlll|}
\hline $\begin{array}{l}\text { Variable } \\
\text { and site }\end{array}$ & $A$ & $\begin{array}{c}E_{\mathrm{a}} \\
\left(\mathrm{kJ} \mathrm{mol}^{-1}\right)\end{array}$ & $\mathrm{R}_{\mathrm{a}}{ }^{2}$ & $\mathrm{n}$ & $Q_{10}$ \\
\hline $\mathbf{G C P}_{\mathrm{m}}$ & & & & & \\
$\mathrm{B}$ & & & 0.07 & 18 & \\
$\mathrm{C}$ & $7.87 \times 10^{14}$ & 79.3 & $0.34^{* *}$ & 19 & 3.43 \\
$\mathrm{E}$ & $1.68 \times 10^{9}$ & 47.9 & $0.18^{*}$ & 18 & 2.11 \\
$\mathrm{~F}$ & $9.40 \times 10^{23}$ & 130.0 & $0.59^{* * *}$ & 16 & 7.60 \\
$\mathbf{C R}$ & & & & & \\
$\mathrm{B}$ & $2.83 \times 10^{13}$ & 73.2 & $0.47^{* * *}$ & 18 & 3.13 \\
$\mathrm{C}$ & $1.82 \times 10^{16}$ & 91.7 & $0.54^{* * *}$ & 19 & 4.17 \\
$\mathrm{E}$ & $3.34 \times 10^{11}$ & 64.1 & $0.43^{* *}$ & 18 & 2.71 \\
$\mathrm{~F}$ & $5.83 \times 10^{24}$ & 139.9 & $0.72^{* * *}$ & 16 & 8.84 \\
\hline
\end{tabular}

GCP on intertidal sandflats during emersion was estimated to be $10.27 \mathrm{~g} \mathrm{C} \mathrm{m}^{-2} \mathrm{yr}^{-1}$.

CR values measured during nighttime emersion periods were not equivalent to those during daytime emersion periods. CR measured at Sites E and F on intertidal sandflats in August 2010 showed that measurements taken during nighttime were about $50 \%$ lower (Table 6). The mean ratio in CR between daytime and nighttime was 1.48. Annual CR on intertidal sandflats during daytime emersion periods was estimated to be $4.44 \mathrm{~g} \mathrm{C} \mathrm{m}^{-2} \mathrm{yr}^{-1}$. Taking into account the variation in $\mathrm{CR}$ during nighttime emersion periods, the annual CR on intertidal sandflats during emersion throughout the day and night was estimated to be
$7.40 \mathrm{~g} \mathrm{C} \mathrm{m}^{-2} \mathrm{yr}^{-1}$. Integrated monthly CR on intertidal sandflats during emersion also showed a clear seasonal pattern. Values were higher in summer and fall and lower in winter and spring (Fig. 8b). Calculated monthly NCP on intertidal sandflats during emersion frequently showed positive values and a clear seasonal pattern (Fig. 8c). These values were higher in summer and lower in winter and spring. Negative values only occurred in October 2008 and June 2009. Annual NCP during emersion on intertidal sandflats was estimated to be $2.87 \mathrm{~g} \mathrm{C} \mathrm{m}^{-2} \mathrm{yr}^{-1}$, indicating a slightly autotrophic system.

\section{Annual budget of potential production throughout a tidal cycle}

During immersion, benthic NCP without shading on intertidal sandflats frequently showed negative values (Table 7). Positive values occurred only at Sites E and $\mathrm{F}$ in July 2006. The highest mean value was recorded at Site F in July 2006 (54.85 $\mathrm{mg} \mathrm{C} \mathrm{m}^{-2} \mathrm{~h}^{-1}$ ), and the lowest value occurred at the same site in January 2006 (-9.57 mg C m ${ }^{-2} \mathrm{~h}^{-1}$ ). Benthic CR generally showed a clear seasonal pattern with values that were higher in July and lower in January (Table 7). Site B showed remarkably higher benthic mean CR in July (94.61 $\mathrm{mg} \mathrm{C} \mathrm{m}^{-2} \mathrm{~h}^{-1}$ ). The lowest values were also measured at the same site in January $\left(11.47 \mathrm{mg} \mathrm{C} \mathrm{m}^{-2}\right.$ $\mathrm{h}^{-1}$ ). Annual benthic CR during immersion on intertidal sandflats was estimated to be $128.79 \mathrm{~g} \mathrm{C} \mathrm{m}^{-2} \mathrm{yr}^{-1}$. Benthic $\mathrm{GCP}_{\mathrm{m}}$ derived from the $P-I$ curves also showed a clear seasonal pattern. There were noticeably higher values in July, but lower values in January (Table 7). The highest benthic $\mathrm{GCP}_{\mathrm{m}}$ oc- 

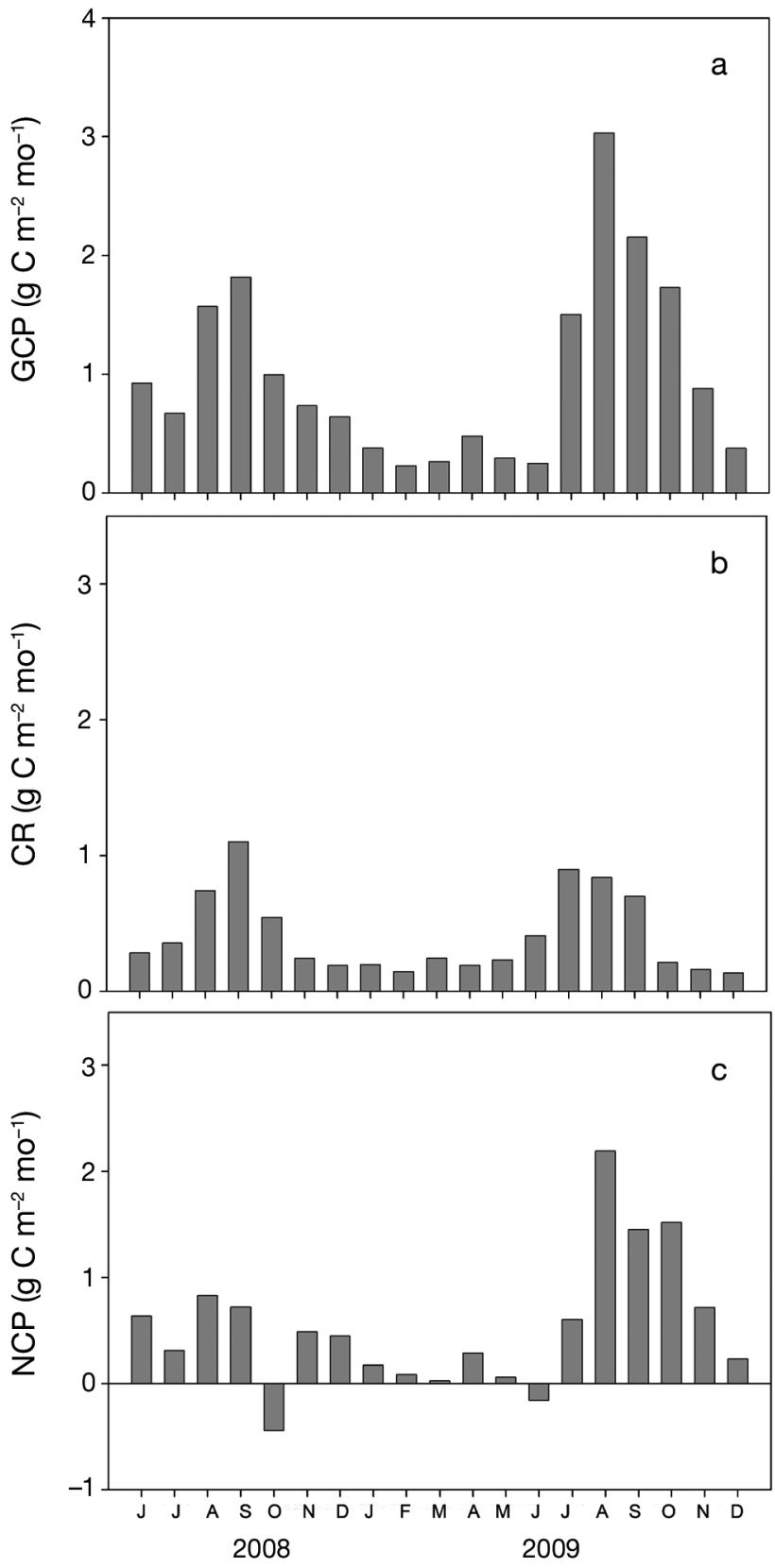

Fig. 8. Calculated monthly changes in (a) gross community production (GCP, $\mathrm{g} \mathrm{C} \mathrm{m}^{-2} \mathrm{mo}^{-1}$ ), (b) community respiration $\left(\mathrm{CR}, \mathrm{g} \mathrm{C} \mathrm{m}^{-2} \mathrm{mo}^{-1}\right.$ ) and (c) net community production (NCP, $\mathrm{g} \mathrm{C} \mathrm{m}^{-2} \mathrm{mo}^{-1}$ ) during emersion on intertidal sandflats of the Kaomei Wetland

Table 6. Community respiration (CR) rates $\left(\mathrm{mg} \mathrm{C} \mathrm{m}^{-2} \mathrm{~h}^{-1}\right)$ (mean $\pm \mathrm{SD}, \mathrm{n}=3$ ) measured in the day and night, and day:night ratios on intertidal sandflats during emersion at

Sites E and F in the Kaomei Wetland in August 2010

\begin{tabular}{|lccc|}
\hline Site & Day & Night & Day:night ratio \\
\hline E & $2.17 \pm 0.29$ & $1.42 \pm 0.02$ & 1.52 \\
F & $1.91 \pm 0.31$ & $1.33 \pm 0.07$ & 1.43 \\
\hline
\end{tabular}

curred at Site F in July $\left(60.30 \mathrm{mg} \mathrm{C} \mathrm{m}^{-2} \mathrm{~h}^{-1}\right)$, and the lowest values occurred at Site E in January ( $0.59 \mathrm{mg} C$ $\mathrm{m}^{-2} \mathrm{~h}^{-1}$ ). No clear spatial pattern of benthic $\mathrm{GCP}_{\mathrm{m}}$ was detected. Annual benthic GCP during immersion on intertidal sandflats was estimated to be $34.45 \mathrm{~g} \mathrm{C} \mathrm{m}^{-2}$ $\mathrm{yr}^{-1}$. Consequently, annual benthic NCP during immersion on intertidal sandflats was estimated to be $-94.34 \mathrm{~g} \mathrm{C} \mathrm{m}^{-2} \mathrm{yr}^{-1}$, indicating a heterotrophic system.

Taking into account the variation in benthic metabolism during immersion and nighttime periods, irradiance corrected for cloud cover and light duration corrected for the migration of benthic diatoms, annual benthic NCP on subtropical intertidal sandflats was calculated to be $-91.47 \mathrm{~g} \mathrm{C} \mathrm{m}^{-2} \mathrm{yr}^{-1}$, indicating that they are carbon sources.

\section{DISCUSSION}

Previous in situ measurements of benthic metabolism were almost exclusively conducted in temperate regions. Very few such measurements have been reported from tropical and subtropical areas (Cahoon 1999), which represents a significant gap in knowledge. Monthly measurements of $\mathrm{GCP}_{\mathrm{m}}$ and $\mathrm{CR}$ taken in the Kaomei Wetland over the 19 mo period showed a clear seasonal pattern, with higher values in summer and lower values in spring and winter (Figs. 6 \& 7). The seasonal pattern in this subtropical coastal wetland was consistent with the seasonal pattern reported by Spilmont et al. (2006) in the temperate Seine Estuary, France. Hubas et al. (2006) concluded that GCP and CR of benthic microalgae were mostly influenced by temperature at Roscoff Aber Bay, France. In the subtropical Kaomei Wetland, the highest $\mathrm{GCP}_{\mathrm{m}}$ values occurred across all 4 study sites during August and September, when air temperature reached $30^{\circ} \mathrm{C}$. Thus, $\mathrm{GCP}_{\mathrm{m}}$ was positively correlated with air temperature. The mean temperature coefficients $\left(Q_{10}\right)$ showed that a rise of $10^{\circ} \mathrm{C}$ would increase the $\mathrm{GCP}_{\mathrm{m}}$ 3.72-fold, which is high compared with the range of 1.4 to 1.7 reported in Roscoff Aber Bay (Hubas et al. 2006). The consistent seasonal pattern across all 4 study sites and the high $Q_{10}$ values suggest that temperature is the main factor influencing intertidal benthic primary production during emersion of coastal wetlands in temperate and subtropical areas.

Our measurements also demonstrated that the summer maximum of $\mathrm{GCP}_{\mathrm{m}}$ in this subtropical intertidal sandflat varied over the study's 2 consecutive years. At the same site, maximum $\mathrm{GCP}_{\mathrm{m}}$ recorded at Site F in August 2009 was almost 3 times that of Sep- 
Table 7. Benthic net community production (NCP, $\mathrm{mg} \mathrm{C} \mathrm{m}^{-2} \mathrm{~h}^{-1}$ ) without shading and community respiration $\left(\mathrm{CR}, \mathrm{mg} \mathrm{C} \mathrm{m}^{-2} \mathrm{~h}^{-1}\right)$ (mean $\pm \mathrm{SD}, \mathrm{n}=3$ ) on intertidal sandflats during immersion at the 4 study sites in the Kaomei Wetland in 2006. Benthic gross community production (GCP) was calculated as the difference between benthic NCP and CR. At each site for each time, the mean value of GCP at each irradiance level was used to fit the $P-I$ curve described by Eq. (1) of Jassby \& Platt (1976) and to calculate the maximum benthic GCP $\left(\mathrm{GCP}_{\mathrm{m}}, \mathrm{mg} \mathrm{C} \mathrm{m}^{-2} \mathrm{~h}^{-1}\right)$

\begin{tabular}{|c|c|c|c|c|c|c|}
\hline \multirow{2}{*}{ Site } & \multicolumn{2}{|c|}{$-\mathrm{NCP}$} & \multicolumn{2}{|l|}{$-\mathrm{CR}$} & \multicolumn{2}{|c|}{$-\mathrm{GCP}_{-}$} \\
\hline & January & July & January & July & January & July \\
\hline $\mathrm{B}$ & $-6.09 \pm 0.66$ & $-19.10 \pm 11.34$ & $11.11 \pm 3.19$ & $94.61 \pm 2.22$ & 7.83 & 51.03 \\
\hline $\mathrm{C}$ & $-4.56 \pm 2.76$ & $-16.37 \pm 7.50$ & $15.45 \pm 11.85$ & $40.56 \pm 4.84$ & 11.66 & 21.56 \\
\hline $\mathrm{E}$ & $-18.64 \pm 4.89$ & $6.46 \pm 3.85$ & $21.24 \pm 2.23$ & $40.54 \pm 2.95$ & 0.59 & 45.95 \\
\hline F & -9.57 & $54.85 \pm 15.14$ & $20.75 \pm 3.37$ & $15.95 \pm 4.74$ & 7.43 & 60.30 \\
\hline
\end{tabular}

tration recovered to the same level of other sites in September 2009 when the biomass of the duck lantern clam noticeably declined.

The great influence of grazing activity by macrofauna on benthic microalgae was evident by the fact that Site B was the only site where the relationship between $\mathrm{GCP}_{\mathrm{m}}$ and air temperature did not fit the exponential curves derived from Hancke \& Glud (2004). Our results suggest that benthic metabolism of coastal wetlands was

tember 2008. However, sediment chl a concentration at Site F in September 2008 (99.71 $\pm 13.55 \mathrm{mg} \mathrm{m}^{-2}$ ) was higher than in August 2009 (50.96 $\pm 9.66 \mathrm{mg}$ $\mathrm{m}^{-2}$ ). The higher summer $\mathrm{GCP}_{\mathrm{m}}$ values in 2009 (versus 2008) probably did not result from a higher biomass of benthic microalgae. It should be noted that the $\mathrm{GCP}_{\mathrm{m}}$ normalized to $\mathrm{chl}$ a or $\mathrm{GCP}_{\mathrm{m}}^{\mathrm{B}}$ in 2009 (1.55 mg C mg chl $\mathrm{a}^{-1} \mathrm{~h}^{-1}$ ) was 5 times that $(0.3 \mathrm{mg} \mathrm{C}$ mg chl $a^{-1} h^{-1}$ ) of 2008. This difference in photosynthetic capacity of benthic microalgae can be attributed to the 2 to $3^{\circ} \mathrm{C}$ higher air temperatures in summer 2009 (Fig. 2). Based on our $Q_{10}$ equation of $\mathrm{GCP}_{\mathrm{m}}$ (Eq. 4) derived from Hancke \& Glud (2004), a rise of $3^{\circ} \mathrm{C}$ would increase the $\mathrm{GCP}_{\mathrm{m}} 1.48$-fold. The increase would approximately correspond with the higher summer maximum of $\mathrm{GCP}_{\mathrm{m}}$ in 2009.

In addition to seasonal variations, we also found spatial variations in CR measurements among the 4 study sites. Site B produced significantly higher CR values than did other sites, particularly in July 2009 when CR at Site B reached the highest value seen during the study period. Bivalves were the most dominant macrofauna at Site $B$, the site closest to the estuary (Table 4). Biomass began to increase in winter and reached its maximum in summer. The high CR at Site B can be attributed to the large biomass of duck lantern clam that was present at the time (Fig. 4). Also in July 2009, the mean sediment chl a concentration reached its highest value (88.09 $\mathrm{mg}$ $\mathrm{m}^{-2}$ ) at Site B (Fig. 3). Using naturally abundant stable carbon and nitrogen isotopes, Antonio et al. (2010) found that resuspended benthic microalgae were an important energy source for Laternula anatina in shallow coastal waters. A large quantity of benthic microalgae might be consumed by L. anatina during summer months and, consequently, sediment chl a concentration was seen to be remarkably lower in August 2009 (Fig. 3). The sediment chl a concen- greatly affected by the grazing activity of macrofauna. Tang \& Kristensen (2007) indicated that changes in solute exchange associated with animals and microbial respiration is a major controlling factor for total sediment metabolism. They estimated that solute exchange can enhance $\mathrm{CO}_{2}$ release by about $50 \%$ in the dark and reduce net primary production by 30 to $50 \%$. Although microbial respiration was not determined in this study, its contribution cannot be ignored, especially in the fine-sand sediments such as found at our study Site E (Hubas et al. 2006). Hubas et al. (2006) concluded that the hierarchy of relative contribution of benthic compartments to CR was in the following order: bacterial respiration $>$ macrofaunal respiration $>$ meiofaunal respiration. Our results, combined with the results of previous studies, clearly demonstrate that knowledge of the interactions among benthic microalgae, macrofauna and bacteria are essential for understanding carbon dynamics in shallow-water sediments.

In most environments studied, the sediment chl a concentration and light availability appear to be the principal determinants of benthic primary production (MacIntyre et al. 1996). Cahoon et al. (1999) indicated the existence of a negative relationship between the proportion of fine sediments and benthic microalgal biomass. Watermann et al. (1999) thought that fine sediment grains would allow for higher nutrient availability and better water retention, and concluded that benthic microalgal biomass is negatively correlated with sediment grain size. Our results also demonstrate that sediment granulometry plays an important role in regulating benthic microalgal biomass and metabolism. We observed a positive correlation trend between sediment chl a concentrations and the silt/clay content, and a negative correlation between sediment chl a concentrations and sediment grain size (Table 3). However, we found that $\mathrm{GCP}_{\mathrm{m}}$ 
was positively correlated with sediment grain size, but negatively correlated with the silt/clay content. In our study, the correlation between $\mathrm{GCP}_{\mathrm{m}}$ and sediment chl a concentrations was not strong. It appears that the biomass of benthic microalgae is not a major factor influencing benthic primary production in intertidal sandflats.

The effects of sediment granulometry on benthic metabolism are still unclear. Davis \& McIntire (1983) found that the annual net primary production in sediments was relatively high in fine sand, but lower in silt. Billerbeck et al. (2007) indicated that the photosynthetic efficiency of benthic microalgae increased in conditions of better light transmission in largegrain sediments. However, Brotas et al. (2003) showed that benthic microalgae were frequently exposed to extreme conditions including supersaturating irradiance, desiccation and high salinity during emersion. Those investigators suggested that prolonged exposure to supersaturating irradiance levels was a major source of stress and a potential limiting factor in benthic primary productivity. Serôdio et al. (2008) found that the light response of most photophysiological parameters of benthic microalgae showed photoinhibition. In our study, the significant positive correlation observed between sediment grain size and $\mathrm{GCP}_{\mathrm{m}}$ indicated that primary production was more likely affected by better light transmission in the sediment of subtropical sandflats. Our results show that, although there was a relationship between sediment granulometry and benthic metabolism dynamics, this relationship was neither as simple nor as linear as suggested in previous studies.

The respiration rate is often assumed to be constant throughout the day and night (Spilmont et al. 2007, Migné et al. 2009). However, our study demonstrated that this might not be the case, although the trend was based on limited data. We found that respiration rates during nighttime were about 50\% lower than during daytime. Accuracy of the respiration budget during emersion on intertidal sandflats was therefore improved by taking nocturnal variations into account. The significant decrease in respiration rates during nighttime is probably due to downward migration of benthic microalgae (Guarini et al. 2000, Serôdio et al. 1997) because of the strong positive correlation between CR measurements and sediment chl a concentration in intertidal sandflats. The other possibility is that respiration rates in intertidal sandflats are temperature dependent. We found that mean $Q_{10}$ values of CR on subtropical intertidal sandflats were 4.80 . A decrease of about $3^{\circ} \mathrm{C}$ at night would lower the CR by about $45 \%$.
Cahoon (1999) estimated primary production of intertidal benthic microalgae to be $111 \pm 99 \mathrm{~g} \mathrm{C} \mathrm{m}^{-2}$ $\mathrm{yr}^{-1}$ in temperate regions and $164 \mathrm{~g} \mathrm{C} \mathrm{m}^{-2} \mathrm{yr}^{-1}$ in tropical regions. However, the value for tropical regions was derived from a single measurement. On intertidal flats in the Ems-Dollard Estuary, Colijn \& de Jonge (1984) found that annual primary production of benthic microalgae ranged from 50 to $250 \mathrm{~g} \mathrm{C}$ $\mathrm{m}^{-2}$ and was closely related to elevation of the tidal flat. Wolfstein et al. (2000) reported wide variations in primary production of benthic microalgae in the northern German Wadden Sea (0.10 to $163.8 \mathrm{~g} \mathrm{C} \mathrm{m}^{-2}$ $\mathrm{yr}^{-1}$ ). In the Seine Estuary of France, the potential GCP of intertidal benthic microalgae was estimated to be $135 \mathrm{~g} \mathrm{C} \mathrm{m}^{-2} \mathrm{yr}^{-1}$ (Spilmont et al. 2006). Our methods were similar to those used in the Seine Estuary, and we estimated the intertidal benthic GCP value (derived over 19 monthly measurements) as being only $10.27 \mathrm{~g} \mathrm{C} \mathrm{m}^{-2} \mathrm{yr}^{-1}$ during emersion.

The annual GCP value observed in the subtropical Kaomei Wetland was only about $10 \%$ of the values reported for temperate and tropical regions as estimated by Cahoon (1999), but was within the range reported for the northern German Wadden Sea (Wolfstein et al. 2000). In the Kaomei Wetland, sediment chl a concentrations were 1.92 to $99.71 \mathrm{mg} \mathrm{m}^{-2}$. Cahoon (1999) summarized chl a values as being $128 \pm 101 \mathrm{mg} \mathrm{m}^{-2}$ in temperate regions and $347 \pm$ $426 \mathrm{mg} \mathrm{m}^{-2}$ in tropical regions. In the northern German Wadden Sea study, Wolfstein et al. (2000) reported that sediment $\mathrm{chl}$ a concentrations were 2.21 to $38.34 \mathrm{mg} \mathrm{m}^{-2}$, and in the Seine Estuary of France, Spilmont et al. (2006) reported that sediment chl a concentrations ranged from 69 to $277 \mathrm{mg} \mathrm{m}^{-2}$. Sediment chl a concentrations in the Kaomei Wetland were $<30 \%$ of those reported in the Seine Estuary study, but were within the range of those recorded in the northern German Wadden Sea. It appears that the lower annual benthic GCP value in this subtropical wetland was partly due to the lower biomass of benthic microalgae.

In the French study, NCP measurements showed that negative values in winter (Spilmont et al. 2006) were attributable to relatively high CR (110 to $188 \mathrm{~g}$ $\mathrm{C} \mathrm{m}^{-2} \mathrm{yr}^{-1}$ ). Consequently, estimated annual benthic $\mathrm{NCP}$ was $-121 \mathrm{~g} \mathrm{C} \mathrm{m}^{-2} \mathrm{yr}^{-1}$ as determined using the measured PAR (Spilmont et al. 2007). In the present study, however, NCP measurements on intertidal sandflats during emersion in winter were still positive (Fig. 8c) owing to the relatively low CR (Fig. 8b). In considering the efflux of $\mathrm{CO}_{2}$ through $\mathrm{CR}$, for most of the year, subtropical intertidal sandflats act as carbon sinks during emersion periods. Annual NCP dur- 
ing emersion in intertidal sandflats was estimated to be $2.87 \mathrm{~g} \mathrm{C} \mathrm{m}^{-2} \mathrm{yr}^{-1}$.

Water turbidity is often thought to prevent photosynthesis by benthic microalgae during immersion (Cayocca et al. 2008). Migné et al. (2009) indicated that respiration rates were always higher under immersed than under emersed conditions. Our results demonstrate that turbid water during immersion increased CR more than GCP, which confirms that primary production of benthic microalgae on intertidal sandflats is restricted to emersion periods. Consequently, taking immersion conditions into account, subtropical intertidal sandflats shifted from a slightly autotrophic status to a heterotrophic status. It is clear that the benthic metabolism requires a considerable subsidy of other sources of organic matter either from the water column or from surrounding vascular plants in order to balance.

\section{CONCLUSIONS}

Benthic metabolism in intertidal sandflats of the subtropical Kaomei Wetland during emersion acts as a carbon sink. Both the $\mathrm{GCP}_{\mathrm{m}}$ and CR measurements showed a clear seasonal pattern with higher values observed in summer and fall and lower values seen in winter and spring. Temperature is an important driving force in benthic metabolism in subtropical intertidal sandflats. Macrofaunal biomass and sediment granulometry play important roles in regulating metabolic functioning. However, taking into account the variation in benthic metabolism during immersion, subtropical intertidal sandflats shift from an autotrophic to a heterotrophic system.

Acknowledgements. This study was supported by the Ministry of Education, Taiwan, ROC, under the ATU plan. We express our appreciation for the comments from 3 anonymous reviewers who helped clarify and strengthen the article.

\section{LITERATURE CITED}

Alpine AE, Cloern JE (1988) Phytoplankton growth rates in a light-limited environment, San Francisco Bay. Mar Ecol Prog Ser 44:167-173

Antonio ES, Kasai A, Ueno M, Won N, Ishihi Y, Yokoyama H, Yamashita Y (2010) Spatial variation in organic matter utilization by benthic communities from Yura RiverEstuary to offshore of Tango Sea, Japan. Estuar Coast Shelf Sci 86:107-117

Barranguet C, Kromkamp J, Peene J (1998) Factors controlling primary production and photosynthetic characteristics of intertidal microphytobenthos. Mar Ecol Prog Ser $173: 117-126$
Billerbeck M, Røy H, Bosselmann H, Huettel M (2007) Benthic photosynthesis in submerged Wadden Sea intertidal flats. Estuar Coast Shelf Sci 71:704-716

Brotas V, Risgaard-Petersen N, Serôdio J, Ottossen L, Dalsgaard T, Riberio L (2003) In situ measurements of photosynthetic activity and respiration of intertidal benthic microalgal communities undergoing vertical migration. Ophelia 57:13-26

Cahoon LB (1999) The role of benthic microalgae in neritic ecosystems. Oceanogr Mar Biol Annu Rev 37:47-86

Cahoon LB, Nearhoof JE, Tilton CL (1999) Sediment grain size effect on benthic microalgal biomass in shallow aquatic ecosystems. Estuaries 22:735-741

Cayocca F, Bassoullet P, Le Hir P, Jestin H, Cann P (2008) Sedimentary processes in a shellfish farming environment, Mont Saint Michel Bay, France. In: Kusuda T, Yamanishi H, Spearman J, Gailani JZ (eds) Sediment and ecohydraulics: INTERCOH 2005. Elsevier, Amsterdam

Chen CTA, Borges AV (2009) Reconciling opposing views on carbon cycling in the coastal ocean: continental shelves as sinks and near-shore ecosystems as sources of atmospheric $\mathrm{CO}_{2}$. Deep-Sea Res II 56:578-590

> Clarke KR, Warwick RM (1994) Similarity-based testing for community pattern: the 2-way layout with no replication. Mar Biol 118:167-176

Colijn F, de Jonge VN (1984) Primary production of microphytobenthos in the Ems-Dollard Estuary. Mar Ecol Prog Ser 14:185-196

Davis MW, McIntire CD (1983) Effects of physical gradients on the production dynamics of sediment-associated algae. Mar Ecol Prog Ser 13:103-114

Guarini JM (2008) Can the intertidal benthic microalgal primary production account for the 'Missing Carbon Sink'? J Oceanogr Res Data 1:13-19

> Guarini JM, Blanchard GF, Gros P (2000) Quantification of the microphytobenthic primary production in European intertidal mudflats - a modeling approach. Cont Shelf Res 20:1771-1788

Hancke K, Glud RN (2004) Temperature effects on respiration and photosynthesis in three diatom-dominated benthic communities. Mar Ecol Prog Ser 37:265-281

Hsieh HL (1995) Spatial and temporal patterns of polychaete communities in a subtropical mangrove swamp: influence of sediment and microhabitat. Mar Ecol Prog Ser 127:157-167

Hsieh HL, Lin HJ (2006) Study on wetland carrying capacity and loading: Kaomei wildlife protected area as an example. Final report to the National Science Council, grant no. NSC94-2621-B-001-007 (with English abstract), Taipei

> Hubas C, Davoult D, Cariou T, Artigas LF (2006) Factors controlling benthic metabolism during low tide in an intertidal bay along a granulometric gradient (Roscoff Aber Bay, western English Channel, France). Mar Ecol Prog Ser 316:53-68

Jassby AD, Platt T (1976) Mathematical formulation of the relationship between photosynthesis and light for phytoplankton. Limnol Oceanogr 21:540-547

Laffoley D, Grimsditch G (eds) (2009) The management of natural coastal carbon sinks. International Union for Conservation of Nature, Gland

> MacIntyre HL, Geider RJ, Miller DC (1996) Microphytobenthos: the ecological role of the 'Secret Garden' of unvegetated, shallow-water marine habitats. I. Distribution, abundance and primary production. Estuaries 19: 186-201 
Meyercordt J, Meyer-Reil LA (1999) Primary production of benthic microalgae in two shallow coastal lagoons of different trophic status in the southern Baltic Sea. Mar Ecol Prog Ser 178:179-191

Migné A, Davoult D, Spilmont N, Menu D, Boucher G, Gattuso JP, Rybarczyk H (2002) A closed-chamber $\mathrm{CO}_{2}$-flux method for estimating intertidal primary production and respiration under emersed conditions. Mar Biol 140: 865-869

> Migné A, Spilmont N, Davoult D (2004) In situ measurements of benthic primary production during emersion: seasonal variations and annual production in the Bay of Somme (eastern English Channel, France). Cont Shelf Res 24:1437-1449

Migné A, Spilmont N, Boucher G, Denis L and others (2009) Annual budget of benthic production in Mont SaintMichel Bay considering cloudiness, microphytobenthos migration, and variability of respiration rates with tidal conditions. Cont Shelf Res 29:2280-2285

Nellemann C, Corcoran E, Duarte CM, Valdés L, De Young C, Fonseca L, Grimsditch G (eds) (2009) Blue carbon. A rapid response assessment. United Nations Environment Programme, GRID-Arendal, Arendal

Parsons TR, Maita Y, Lalli CM (1984) A manual of chemical and biological methods for seawater analysis. Pergamon Press, New York, NY

> Peterson BJ, Howarth RW (1987) Sulfur, carbon, and nitrogen isotopes used to trace organic matter flow in the saltmarsh estuaries of Sapelo Island, Georgia. Limnol Oceanogr 32:1195-1213

Schelske CL, Odum EP (1962) Mechanisms maintaining high productivity in Georgia estuaries. Proc Gulf Caribb Fish Inst 14:75-80

Schindler DW (1999) The mysterious missing sink. Nature 398:105-106

Editorial responsibility: Rodney Foster,

Lowestoft, UK
Serôdio J, Silva JM, Catarino F (1997) Nondestructive tracing of migratory rhythms of intertidal benthic microalgae using in vivo chlorophyll a fluorescence. J Phycol 33: 542-553

Serôdio J, Vieira S, Cruz S (2008) Photosynthetic activity, photoprotection and photoinhibition in intertidal microphytobenthos as studied in situ using variable chlorophyll fluorescence. Cont Shelf Res 28:1363-1375

Smetacek V (1999) Diatoms and the ocean carbon cycle. Protist 150:25-32

Spilmont N, Davoult D, Migné A (2006) Benthic primary production during emersion: in situ measurements and potential primary production in the Seine Estuary (English Channel, France). Mar Pollut Bull 53:49-55

Spilmont N, Migné A, Seuront L, Davoult D (2007) Shortterm variability of intertidal benthic community production during emersion and the implication in annual budget calculation. Mar Ecol Prog Ser 333:95-101

Sullivan MJ, Moncrieff CA (1990) Edaphic algae are an important component of salt marsh food-webs: evidence from multiple stable isotope analyses. Mar Ecol Prog Ser 62:149-159

> Tang M, Kristensen E (2007) Impact of microphytobenthos and macroinfauna on temporal variation of benthic metabolism in shallow coastal sediments. J Exp Mar Biol Ecol 349:99-112

> Watermann F, Hillebrand H, Gerdes G, Krumbein WE, Sommer U (1999) Competition between benthic cyanobacteria and diatoms as influenced by different grain sizes and temperatures. Mar Ecol Prog Ser 187:77-87

Wolfstein K, Colijn F, Doerffer R (2000) Seasonal dynamics of microphytobenthos biomass and photosynthetic characteristics in the Northern German Wadden Sea, obtained by the photosynthetic light dispensation system. Estuar Coast Shelf Sci 51:651-662

Submitted: November 1, 2010; Accepted: August 24, 2011 Proofs received from author(s): October 25, 2011 